Article

\title{
Effects of Sales, Receivables Turnover, and Cash Flow on Liquidity
}

Rusdiyanto $^{1}$

$1 * \mathrm{PhD}$ Student of Faculty of Economics and Business, Universitas Airlangga Indonesia

$1 * *$ Lecturer of the Faculty of Economics, Universitas Gresik Indonesia

Dian Agustia ${ }^{2}$

${ }^{2}$ Professor of accounting and lecturer of Faculty of Economics and Business,

Universitas Airlangga Indonesia

Soegeng Soetedjo ${ }^{3}$

${ }^{3}$ Professor of accounting and lecturer of Faculty of Economics and Business,

Universitas Airlangga Indonesia

Dina Fitrisia Septiarini ${ }^{4}$

${ }^{4}$ Lecturer of Faculty of Economics and Business, Universitas Airlangga Indonesia

Susetyorini ${ }^{5}$, Umi Elan ${ }^{6}$, Mochamad Syafii ${ }^{7}$, Bustanul Ulum ${ }^{8}$, Petrus Suparman', Dwi Inggarwati Rahayu ${ }^{10}$, Dini kusumaningrum ${ }^{11}$,

5, 6,7,8,9,10,11, Lecturer of Faculty of Economics, Universitas Gresik Indonesia

Received 14 November 2019; Received December 2019; Accepted December 2019

Abstract: In this study, the author proposes to evaluate the effect of sales growth, Receivable Turnover and operating cash flow on the liquidity of PT. Unilever Indonesia Plc. The research method used is descriptive method with a

${ }^{1}$ Corresponding author : rusdiyanto.se.m.ak-2017@feb.unair.ac.id

* PhD Student of Faculty of Economics and Business, Universitas Airlangga Indonesia, Jl. Airlangga No.4, Airlangga, Gubeng, Surabaya, East Java 60286 Indonesia

**Lecturer of the Faculty of Economics, Universitas Gresik Indonesia, Jl. Arif Rahman Hakim No.2B, Gresik, City Gresik, East Java 60111 Indonesia

2 Corresponding author : dian.agustia@feb.unair.ac.id

Professor of accounting and lecturer of Faculty of Economics and Business, Universitas Airlangga Indonesia, Jl. Airlangga No.4, Airlangga, Gubeng, Surabaya, East Java 60286 Indonesia

${ }^{3}$ Corresponding author : soegeng.sutejo@febis.unair.ac.id

Professor of accounting and lecturer of Faculty of Economics and Business, Universitas Airlangga Indonesia, Jl. Airlangga No.4, Airlangga, Gubeng, Surabaya, East Java 60286 Indonesia

${ }^{4}$ Corresponding author : dina.fitrisia@feb.unair.ac.id Lecturer of Faculty of Economics and Business, Universitas Airlangga Indonesia, Jl. Airlangga No.4, Airlangga, Gubeng, Surabaya, East Java 60286 Indonesia

${ }^{5}$ Corresponding author : susetyorini@gmail.com

Lecturer of the Faculty of Economics, Universitas Gresik Indonesia, Jl. Arif Rahman Hakim No.2B, Gresik, City Gresik, East Java 60111 Indonesia

${ }^{6}$ Corresponding author : umi.elan1@gmail.com

Lecturer of the Faculty of Economics, Universitas Gresik Indonesia, Jl. Arif Rahman Hakim No.2B, Gresik, City Gresik, East Java 60111 Indonesia

${ }^{7}$ Corresponding author : syafiimochamad87@gmail.com

Lecturer of the Faculty of Economics, Universitas Gresik Indonesia, Jl. Arif Rahman Hakim No.2B, Gresik, City Gresik, East Java 60111 Indonesia

${ }^{8}$ Corresponding author : bustanululum46@gmail.com

Lecturer of the Faculty of Economics, Universitas Gresik Indonesia, Jl. Arif Rahman Hakim No.2B, Gresik, City Gresik, East Java 60111 Indonesia

${ }_{9}^{9}$ Corresponding author : petrus.unigres@gmail.com

Lecturer of the Faculty of Economics, Universitas Gresik Indonesia, Jl. Arif Rahman Hakim No.2B, Gresik, City Gresik, East Java 60111 Indonesia

${ }^{10}$ Corresponding author : winggar7@gmail.com

Lecturer of the Faculty of Economics, Universitas Gresik Indonesia, Jl. Arif Rahman Hakim No.2B, Gresik, City Gresik, East Java 60111 Indonesia

${ }^{11}$ Corresponding author : dhinning.room2@gmail.com

Lecturer of the Faculty of Economics, Universitas Gresik Indonesia, Jl. Arif Rahman Hakim No.2B, Gresik, City Gresik, East Java 60111 Indonesia 
quantitative approach. In this statement, the population used in this study is the financial statement data from PT. Unilever Indonesia Plc. from 2010 to 2018, the technique of determining the sampling uses Purposive Sampling. This research data uses secondary data from PT. Unilever Indonesia Plc financial statements from 2010 to 2018 . All data sources were obtained from the website of the Indonesia Stock Exchange at https://www.idx.co.id, the company's website and Google search. Our analysis reveals that sales growth and accounts receivable turnover from PT. Unilever Indonesia PIc. has no influence on the liquidity of PT. Unilever Indonesia Plc, while operating cash flow has an influence on the Liquidity of PT Unilever Indonesia PIc. This means the ups and downs of the value of sales and accounts receivable turnover of a company has no influence on the liquidity of PT. Unilever Indonesia PIc, while operating cash flow has increased or decreased has an influence on the liquidity of PT Unilever Indonesia Plc. The value of sales growth, accounts receivable turnover and operating cash flow can explain the liquidity of PT Unilever Indonesia Plc. by $78 \%$, while $22 \%$ is explained by other factors which are not included in this study.

Keywords: Sales, Receivables, Cash Flow, Liquidity.

JEL Classification: 010, 014, A12

\section{Introduction}

The economic conditions in Indonesia have reached the era of globalization where a company is demanded to increase productivity, competitiveness, and business profits in order to maintain its existence through effective and efficient productivity. The company has the ability to develop and maintain its existence as a sustainable company and be able to deal with the conditions of economic development in the future. The main purpose of the company is to make a profit. One of the activities in order to make a profit is selling. For trading companies that revenue is derived from sales activities, both cash sales and credit sales. For service companies income is obtained from the results of service activities. Manufacturing company income is obtained from the activity of producing an item from the management of raw materials then the goods in the process until the finished goods are ready for sale to consumers.

Previous research explains that sales are an important aspect that is the main focus of a company. Therefore the company must manage sales activities carefully and with good sales procedures so that high and continuous fluctuations occur (Haris, Yao, Tariq, Javaid, \& UI Ain, 2019; S. T. Kim \& Choi, 2019; Sundaram, 2019; Zhang, He, Qin, Fu, \& He, 2019). While receivables are one element of current assets in the statement of financial position arising from the sale of goods or services on credit. Receivables can also arise when the company provides loans to other companies or other parties that are outstanding. Companies must manage trade receivables appropriately because trade receivables are second only to cash, meaning that trade receivables are highly liquid assets (Aqil, Ahmed, Vveinhardt, \& Streimikiene, 2019; Huan, Gaoping, \& Dan, 2017; Hung, Ha, \& Binh, 2018; S. Y. Kim, 2018; Yakymova \& Kuz, 2019). The cash flow statement is one tool to measure the level of company liquidity. A company can be said to be liquid if the company can meet its short-term financial obligations in accordance with the specified time period (Cai, Kim, Li, \& Pan, 2019; El-Diftar \& Elkalla, 2019; C. Nguyen, 2019; H. A. Nguyen \& Nguyen, 2020). The level of liquidity of a company is usually used as a benchmark for decision making for parties related to the company perusahaan (Alhassan \& Naka, 2020; Díaz \& Escribano, 2020; Dustan, 2020; Srinivasan, 2020)..

This research provides a number of contributions. The results of the study identify the important problems currently in Indonesia, where sales growth, accounts receivable turnover and operating cash flow have a positive influence on the liquidity of PT Unilever Indonesia Plc. which focuses the right attention on the company's operations. Our findings show that sales growth and accounts receivable turnover do not have an effect on the liquidity of PT Unilever Indonesia Plc, while operating cash flow has a positive effect on the liquidity of PT Unilever Indonesia Plc. As such, this research expands our knowledge of sales growth, accounts receivable turnover and operating cash flow with Company Liquidity in Indonesia.

The remnant of the study is organized as follows. The next section outlines relevant research and develops hypotheses. Section 3 details the sample, variables, and empirical model. Section 4 provides analysis and empirical results. Section 5 outlines the conclusions and implications of the study.

\section{Literature Review And Hypotheses}

\subsection{Agency Theory}

Agency theory explains the relationship between management and shareholders. Agency problems often occur between investors or creditors and management (Jensen \& Meckling, 1976). Improving the financial performance of the company provides management options for developing the company to improve shareholder welfare.

\subsection{Selling}

Sale is the transfer of ownership of goods or services provided by the seller to the buyer at an agreed price along with the amount charged to customers in the sale of goods / services in an accounting period. The sale is a transfer of ownership of the goods in exchange for money in exchange for approval to hand over the goods to another party by receiving payment pembayaran (Haris, Yao, Tariq, Javaid, \& UI Ain, 2019; S. T. Kim \& Choi, 2019; Sundaram, 2019; Zhang, $\mathrm{He}$, Qin, Fu, \& He, 2019).. Sales are also a source of company income, the greater the sales, the greater the income 
earned by the company, sales are purchases of goods or services from one party to another party by getting compensation from that party.

\subsection{Receivable}

Receivables represent the value time deadline derived from the value of the sale of goods or services from lending money. Receivables include the value of the deadline from activities such as rent and interest. (Aqil et al., 2019; Huan et al., 2017; Hung et al., 2018; S. Y. Kim, 2018; Yakymova \& Kuz, 2019) explain that receivables are the company's claims for money, goods, or services to other parties due to transactions in the past, receivables represent a sum of money owed by consumers to companies that buy goods and services on credit to the company, a number of bills to be received by companies from other parties, both as a result of delivering goods and services on credit or as a result of overpayments of cash to other parties. Receivables can arise not only because of credit sales but can be due to other things, such as receivable to employees, receivables due to the sale of fixed assets on credit, receivables due to the sale of shares on credit or the existence of advances for purchases or other employment contracts. Receivables are classified as current assets if they are expected to be realized or billed within one year or one operating cycle.

\subsection{Cash flow}

The cash flow statement is a report on the company's cash receipts and disbursements activities for a certain period, along with an explanation of the sources of cash receipts and disbursements (Cai, Kim, Li, \& Pan, 2019; El-Diftar \& Elkalla, 2019; C. Nguyen, 2019; H. A. Nguyen \& Nguyen, 2020). The cash flow statement provides relevant information about the cash receipts and disbursements of a company in a certain period, by classifying transactions in activities: operations, financing and investment. Cash flow statement is a financial statement that reports the amount of cash received and paid by a company during a certain period, cash flow statement is a report that provides information about the company's cash inflows and outflows in a certain period.

\subsection{Liquidity}

Liquidity is the company's ability to meet short-term obligations by looking at the company's current assets relative to its debt. (Alhassan \& Naka, 2020; Díaz \& Escribano, 2020; Dustan, 2020; Srinivasan, 2020) Liquidity is related to the problem of a company's ability to meet its financial obligations which must immediately be met. The amount of payment instruments owned by a company at one time is the paying power of the company concerned, liquidity measures the company's ability to repay short-term obligations on time, including paying off the portion of long-term debt that is due in the year, liquidity is the ability a company fulfills its short-term obligations and the company is said to be liquid if the company can fulfill its short-term obligations in a timely manner.

\subsubsection{Effect of Sales Growth Against Liquidity Level}

Sales growth is an increase in the number of sales from year to year or from time to time, an increase in sales and services between the current year and the previous year. This shows that the level of Liquidity is influenced by Sales Growth ((Arora et al., 2019; Cabrilo \& Leung, 2019; Haris et al., 2019; S. T. Kim \& Choi, 2019; Sundaram, 2019; Zhang et al., 2019). Based on the arguments above, the hypotheses tested are as follows: $\mathrm{H}_{1}$ : Sales growth has a positive effect on the level of liquidity

\subsubsection{Effects of Receivables Turnover Against Liquidity}

Receivables turnover is a ratio used to measure how long the collection of receivables during a period or the number of times the funds invested in these receivables revolve in one period periode (Aqil et al., 2019; Huan et al., 2017; Hung et al., 2018; S. Y. Kim, 2018; Yakymova \& Kuz, 2019). The higher the ratio of working capital invested in receivables, the lower (compared to the ratio of the previous year) and of course this condition for the company will be better. This shows that the size of the Liquidity Level is influenced by Receivables Turnover. Based on the arguments above, the hypotheses tested are as follows:

$\mathrm{H}_{2}$ : Receivables turnover has a positive effect on Liquidity Level

\subsubsection{Effect of Operating Cash Flow Against Liquidity Level}

Cash flow operating activities are activities related to the company's efforts to produce products as well as all efforts related to selling products. This shows that the level of liquidity is affected by Operating Cash Flow (Cai, Kim, Li, \& Pan, 2019; El-Diftar \& Elkalla, 2019; C. Nguyen, 2019; H. A. Nguyen \& Nguyen, 2020). Based on the arguments above, the hypotheses tested are as follows:

$\mathrm{H}_{3}$ : Operating Cash Flow has a positive effect on the Liquidity Level 


\section{Research methods}

\subsection{Type of Research Approach}

The type in this research is quantitative research whose analysis uses data measured on a numerical scale tested using statistical analysis. Quantitative descriptive is a research design that aims to explain or provide empirical evidence about a particular phenomenon accompanied by quantitative and qualitative data extracted from an object

\subsection{Definition of Operational Variables}

The definition of operational variable is a study or limitation used to regulate the relationship of two or more variables in a hypothesis. The variables used in this study are to get an idea of the problem under study, then the definition of operational used and discussed by researchers is as follows:

1) Sales Growth $\left(X_{1}\right)$

Sales growth represents an increase in sales from period to period. The high level of sales growth shows the better the company is in carrying out its operations (Haris, Yao, Tariq, Javaid, \& UI Ain, 2019). Sales growth can be calculated using the following formula:

$$
\text { Sales Growth }=\frac{\text { Year Sales } t-\text { Year Sales } t-1}{\text { Year Sales } t-1}
$$

2) Receivables Turnover $\left(\mathrm{X}_{2}\right)$

Receivables turnover is a ratio used by companies to measure how long these receivables can be collected in a certain period. The ratio can be calculated by dividing net sales by the average trade receivables (Aqil et al., 2019; Huan et al., 2017; Hung et al., 2018; S. Y. Kim, 2018; Yakymova \& Kuz, 2019). The statement is presented in the form of a formula as follows:

$$
\text { Receiveable Turn Over }=\frac{\text { Net sales }}{\text { Average Receivables }}
$$

3) Operating Cash Flow $\left(X_{3}\right)$

The cash flow statement is part of a company's financial statements that are generated in an accounting period that shows the company's cash inflows and cash outflows. In this study the indicator used is the ratio of cash flows from operating activities (El-Diftar \& Elkalla, 2019; C. Nguyen, 2019). In this study Operating Cash Flow is calculated as "Changes in Operating Cash Flow", which is the difference between cash obtained from operational activities in the current period $(t)$ minus cash obtained from operational activities in the previous period (t-1), divided by cash obtained from activities previous operational period $(t-1)$, the formula of which is shown as follows:

4) Liquidity $(\mathrm{Y})$

$$
\text { Cash Flow Operating }=\frac{C F O-C F O t-1}{C F O t-1}
$$

Liquidity is the company's ability to meet its short-term obligations, and the company is said to be liquid if the company can fulfill its short-term obligations in a timely manner. Liquidity has several ratios to measure the overall effectiveness of management as indicated by the size of the company's ability to meet its short-term obligations. Here researchers try to use current. This Current Ratio also shows the efficiency of a company's operating cycle or its ability to turn products into cash. Current Ratio which is one of the Liquidity Ratio Analysis is also known as the Capital Ratio (Alhassan \& Naka, 2020). The formula used to calculate the current ratio is as follows:

$$
\text { Current Ratio }=\frac{\text { Current Asset }}{\text { current liabilitas }}
$$

\subsection{Population, Samples and Sampling Techniques}

The population in this study is the financial statement data of PT. Unilever Indonesia Plc. from 2010 to 2018 , the sample in this study is the financial statement data from PT. Unilever Indonesia Plc. From 2010 to 2018. The sampling technique used in this study is the financial statement data from PT. Unilever Indonesia Plc. in 2010 until 2018. This research goes through several stages that must be taken to be able to know how the influence of the variable Sales Growth, Receivable Turnover, and Operating Cash Flow on the Liquidity Level of PT. Unilever Indonesia Plc. during the period 2010 to 2018. The data analysis technique in this study uses multiple linear regression analysis to determine the accuracy of the relationship between the Liquidity Level variable and the variable Sales Growth, Receivable Turnover, and Operating Cash Flow. 


\section{Discussion of Research Results}

\subsection{Research result}

The linearity test aims to see whether the regression model can be approximated by linear equations. The conclusion is when the $p$-value F-Statistic $>0.05$, the research model used is linear. Here are the results of the linearity test:

Table 1. Linearity Test of Sales Growth $\left(\mathrm{X}_{1}\right)$

\begin{tabular}{|c|c|c|c|c|c|c|c|}
\hline & & & Sum of Squares & df & Mean Square & $\mathrm{F}$ & Sig. \\
\hline \multirow{5}{*}{$\begin{array}{l}\text { Liquidity Level * Sales } \\
\text { Growth }\end{array}$} & \multirow[t]{3}{*}{ Between Groups } & (Combined) & .179 & 31 & .006 & 1.228 & .504 \\
\hline & & Linearity & .012 & 1 & .012 & 2.500 & .212 \\
\hline & & $\begin{array}{l}\text { Deviation from } \\
\text { Linearity }\end{array}$ & .167 & 30 & .006 & 1.186 & .519 \\
\hline & Within Groups & & .014 & 3 & .005 & & \\
\hline & Total & & 193 & 34 & & & \\
\hline
\end{tabular}

Based on the table above, the linearity test results for Sales Growth and Liquidity variables show a p-value of 0.519> 0.05 , so it can be concluded that the regression model in this study is linear.

Table 2. Linearity Test of Receivables Turnover $\left(\mathrm{X}_{2}\right)$

\begin{tabular}{|c|c|c|c|c|c|c|c|}
\hline & & & Sum of Squares & df & Mean Square & $\mathrm{F}$ & Sig. \\
\hline \multirow{5}{*}{$\begin{array}{l}\text { Liquidity Level * } \\
\text { Receivables Turnover }\end{array}$} & \multirow[t]{3}{*}{ Between Groups } & (Combined) & .188 & 31 & .006 & 3.857 & .146 \\
\hline & & Linearity & .001 & 1 & .012 & .425 & .561 \\
\hline & & $\begin{array}{l}\text { Deviation from } \\
\text { Linearity }\end{array}$ & .187 & 30 & .006 & 3.972 & .141 \\
\hline & Within Groups & & .005 & 3 & .005 & & \\
\hline & Total & & 193 & 34 & & & \\
\hline
\end{tabular}

Based on the table above the results of the linearity test for the variable Receivables Turnover and Liquidity showed a p-value of $0.141>0.05$, so it can be concluded that the regression model in this study is linear.

Table 3. Linearity Test of Operating Cash Flow $\left(X_{3}\right)$

\begin{tabular}{|c|c|c|c|c|c|c|c|}
\hline & & & Sum of Squares & df & Mean Square & $\mathrm{F}$ & Sig. \\
\hline \multirow{5}{*}{$\begin{array}{l}\text { Liquidity Level * Cash flow } \\
\text { Operation }\end{array}$} & \multirow[t]{3}{*}{ Between Groups } & (Combined) & .187 & 31 & .006 & 1.050 & .664 \\
\hline & & Linearity & .030 & 1 & .030 & 5.616 & .254 \\
\hline & & $\begin{array}{l}\text { Deviation from } \\
\text { Linearity }\end{array}$ & .157 & 32 & .005 & .907 & .698 \\
\hline & \multicolumn{2}{|l|}{ Within Groups } & .005 & 1 & .005 & & \\
\hline & \multicolumn{2}{|l|}{ Total } & .193 & 34 & & & \\
\hline
\end{tabular}

Based on the table above, the linearity test results for the Operating Cash Flow and Liquidity variables show a p-value of $0.698>0.05$, so it can be concluded that the regression model in this study is linear.

\subsubsection{Coefficient of Determination $\left(R^{2}\right)$}

The coefficient of determination is used to find out how much the percentage of contributions made by the model used in the study are company size, leverage and ROA to earnings management in telecommunications companies listed on the Indonesia Stock Exchange.

Table 4. Coefficient of Determination $\left(\mathbf{R}^{2}\right)$

\begin{tabular}{cccc} 
Model & $\mathrm{R}$ & $\mathrm{R}$ Square & Adjusted R Square \\
\hline 1 & $.471^{\mathrm{a}}$ & 222 & .078
\end{tabular}

From the table above it is known that the value of Adjusted R Square is 0.78 or $78 \%$. It can be interpreted that the independent variable consisting of Sales Growth, Accounts Receivable Turnover and Operating Cash Flow can explain the dependent variable namely Liquidity of $78 \%$, while $22 \%$ is explained by other factors which is not included in this study.

\subsubsection{T-test}

T-test partially tests the regression coefficient to find out whether each model used in the study of sales growth, accounts receivable turnover and operating cash flow has an effect on liquidity at PT. Unilever Indonesia Plc. listed on the Indonesia Stock Exchange. 
Table 5. T-Test Results

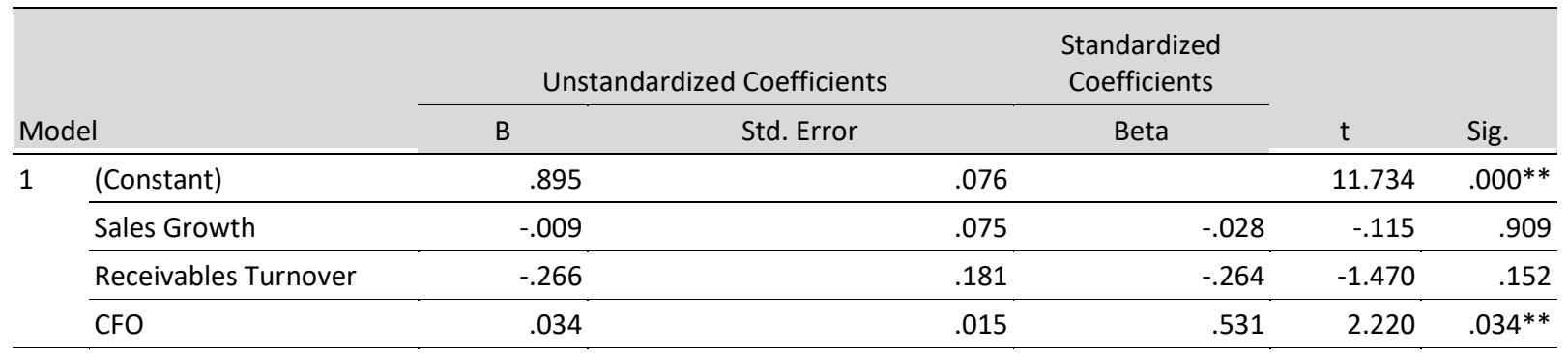

a. Dependent Variable: Liquidity

The table above shows the results of the t-test in this study, which is as follows: The independent variable Sales Growth has a significance value of $0.909>0.05$ which can be concluded that the variable Sales Growth has no significant effect on the level of liquidity. So it is said to reject the hypothesis, the independent variable of Receivable Turnover has a significance value of $0.152>0.05$ which can be concluded that the Receivable Turnover variable has no significant effect on the Liquidity Level. So it is said to reject the hypothesis, the independent variable Operating Cash Flow has a significance value of $0.034<0.05$ which can be concluded that the Operating Cash Flow variable has a positive and significant effect on the Liquidity Level. So the hypothesis is accepted.

\subsubsection{F-Test}

The F-test is used to evaluate all the independent variables on the dependent variable. Does the independent variable simultaneously affect the dependent variable? The significance level is $5 \%$. The following are the results of the F-test (simultaneous) in this study:

\begin{tabular}{llrrrrrr}
\hline Model & Sum of Squares & df & Mean Square & $F$ & Sig. \\
1 & .043 & 3 & .014 & 2.948 & $.048^{a^{* *}}$ \\
\cline { 2 - 8 } & Regression & .150 & 31 & .005 & & \\
\hline Residual & .193 & 34 & & & \\
\hline Total & & & & & & \\
\hline
\end{tabular}

a. Predictors: (Constant), Sales, Receivables, CFO

b. Dependent Variable: Liquidity

The table above shows that the F-test results were 0.048 with a significance level of $0.048<0.05$. Then it can be concluded that the hypothesis is accepted so that the independent variables namely Sales Growth, Receivable Turnover, and Cash Flow simultaneously have a positive effect on the Liquidity variable.

\subsubsection{Multiple Linear Regression Test}

Multiple linear regression analysis is to measure and determine the causal relationship between one variable with another variable. In this study there is one dependent variable and three independent variables so multiple regression analysis is used.

Table 7. Multiple Regression Test Results

\begin{tabular}{llccr}
\hline \multirow{2}{*}{ Model } & Unstandardized Coefficients & & \multicolumn{2}{c}{$\begin{array}{c}\text { Standardized } \\
\text { Coefficients }\end{array}$} \\
\hline 1 & (Constant) & Std. Error & Beta \\
\cline { 2 - 5 } & Sales growth & .895 & .076 & \\
\cline { 2 - 5 } & Receivable Turnover & -.009 & .075 & -.028 \\
\cline { 2 - 5 } & Operating cash flow & -.266 & .181 &. .264 \\
\hline
\end{tabular}

a. Dependent Variable: Liquidity

The multiple linear regression formula in this study is as follows:

$\mathrm{Y}=\mathrm{a}+\mathrm{b} 1 \mathrm{X} 1+\mathrm{b} 2 \mathrm{X} 2+\mathrm{b} 3 \mathrm{X} 3+\mathrm{e}(\mathrm{Y}=0.895-0.909 \mathrm{X} 1-0,266 \mathrm{X} 2+0,034 \mathrm{X} 3+\mathrm{e})$

The regression equation can be explained as follows:

The constant value of 0.895 indicates the variable Sales Growth, Receivable Turnover, and Operating Cash Flow of zero or constant, then the value of the Liquidity Level is 0.895 , the regression coefficient value of the Sales Growth variable is -0.009 , meaning that if Sales Growth is increased by one unit then the Rate Liquidity decreased by 0.009 and vice versa with the other variable conditions constant, the value of the variable regression coefficient Receivable Turnover by -0.266 , means that if the Receivables Turnover increased by one unit then the Liquidity Rate decreased by 0.266 and vice versa with the other variable conditions constant, Value regression coefficient variable Operating Cash Flow is $\mathbf{0 . 0 3 4}$, meaning that if the Operating Cash Flow is increased by one unit, the Liquidity Level rises by 0.034 and vice versa with other variable conditions constant. 


\subsection{Discussion and Research Results}

\subsubsection{Effect of Partial Sales Growth against Liquidity Level}

Sales growth is an increase in the number of sales from year to year or from time to time. Sales growth: refers to the increase in sales and services between the current year and the previous yearHypothesis test results the effect of Sales Growth on the Liquidity Level with the value of t-count -0.009 with a significance level of $0.909>0.05$. So it can be concluded that the variable Sales Growth has no influence on the level of liquidity. This means that the level of Liquidity of PT Unilever Indonesia PIc. is not affected by Sales Growth.

\subsubsection{The Effect of Partially Receivable Turnover against Liquidity Level}

Receivables turnover is a ratio used to measure how long the collection of receivables during a period or the number of times funds invested in receivable revolve in one period. The higher the ratio level, it shows that the working capital invested in receivables is lower and of course this condition for the company is getting better. Hypothesis test results the influence of Accounts Receivable Turnover on the Liquidity Level with a value of t-count of- 0.266 with a significance level of 0.152> 0.05. This means that the Accounts Receivable Turnover variable has no effect on the Liquidity Level of PT Unilever Indonesia Plc. This shows that the level of Liquidity is not affected by the Receivable Turnover of PT. Unilever Indonesia Plc.

\subsubsection{The Effect of Operational Cash Flow Partially on the Liquidity Level}

Cash flows from operating activities are activities related to the company's efforts to produce products as well as all efforts related to selling products. Hypothesis test results on the effect of Operating Cash Flow on Liquidity Level with a value of $t$-count of 0.034 with a significance level of $0.034<0.05$. This means that it can be concluded that the Operating Cash Flow has a positive and significant effect on the Liquidity Level of PT. Unilever Indonesia Plc. This shows that the level of Liquidity is influenced by the Operating Cash Flow of PT. Unilever Indonesia Plc.

5.1.4 Effects of Sales Growth, Receivable Turnover, and Operating Cash Flows Simultaneously against Liquidity Level

The results of the hypothesis test simultaneously obtained an F value of 2.948 with a significance level of 0.048 $<0.05$. Then it can be concluded that Sales Growth, Receivable Turnover, and Operating Cash Flow simultaneously have a positive and significant influence on the Liquidity Level of PT. Unilever Indonesia Plc.

\section{Conclusion}

Sales growth has no effect on liquidity, meaning that sales growth cannot affect company liquidity. Sales growth shows the amount of company liquidity information, so sales growth becomes a part related to the company's financial performance. Accounts Receivable Turnover has no effect on company liquidity, meaning that the amount of receivable turnover in the company can affect company liquidity. While operating cash flow has a positive effect on company liquidity. This means the rise and fall of the value of a company's operating cash flow affects the company's liquidity. The value of Adjusted R Square of 78\%, that the variable sales growth, accounts receivable turnover and operating cash flow can explain the company's liquidity variable by $78 \%$, while $22 \%$ is explained by other factors which are not included in this study.

\section{References}

1. Alhassan, A., \& Naka, A. (2020). Corporate future investments and stock liquidity: Evidence from emerging markets. International Review of Economics and Finance, 65, 69-83.

2. Aqil, M., Ahmed, R. R., Vveinhardt, J., \& Streimikiene, D. (2019). Factors influencing the profitability of heavy vehicle industry: A case of Pakistan. Montenegrin Journal of Economics, 15(1), 61-72.

3. Arora, L., Kumar, S., \& Verma, P. (2019). Is growth risky? Evidence from India. Research in Finance, 35, 53-70.

4. Baulkaran, V. (2019). Stock market reaction to green bond issuance. Journal of Asset Management, 20(5), 331-340.

5. Cabrilo, S., \& Leung, R. (2019). Do leaders really matter in knowledge management practices? Case of Serbian Companies. International Journal of Knowledge Management, 15(4), 94-113.

6. Cai, Y., Kim, Y., Li, S., \& Pan, C. (2019). Tone at the top: CEOs' religious beliefs and earnings management. Journal of Banking and Finance, 106, 195-213.

7. Díaz, A., \& Escribano, A. (2020). Measuring the multi-faceted dimension of liquidity in financial markets: A literature review. Research in International Business and Finance, 51.

8. Dustan, A. (2020). Can large, untargeted conditional cash transfers increase urban high school graduation rates? Evidence from Mexico City's Prepa Sí. Journal of Development Economics, 143.

9. El-Diftar, D., \& Elkalla, T. (2019). The value relevance of accounting information in the MENA region: A comparison of GCC and non-GCC country firms. Journal of Financial Reporting and Accounting, 17(3), 519-536.

10. Haris, M., Yao, H., Tariq, G., Javaid, H. M., \& UI Ain, Q. (2019). Corporate governance, political connections, and bank performance. International Journal of Financial Studies, 7(4).

11. Huan, L., Gaoping, Z., \& Dan, L. (2017). Do big customers influence listed firms' performance? Based on suppliercustomer relationships in China. China Journal of Accounting Studies, 5(3), 326-343.

12. Hung, D. N., Ha, H. T. V, \& Binh, D. T. (2018). Impact of accounting information on financial statements to the stock price of the energy enterprises listed on vietnam's stock market. International Journal of Energy Economics and 
Policy, 8(2), 1-6. Retrieved from.

13. Jensen, M. C., \& Meckling, william H. (1976). Theory of The Firm: Managerial Behavior, Agency Cost And Ownership Structure. Journal of Financial Economics, 3, 305-360.

14. Kim, S. T., \& Choi, B. (2019). Price risk management and capital structure of oil and gas project companies: Difference between upstream and downstream industries. Energy Economics, 83, 361-374.

15. Kim, S. Y. (2018). Predicting hospitality financial distress with ensemble models: the case of US hotels, restaurants, and amusement and recreation. Service Business, 12(3), 483-503.

16. Nguyen, C. (2019). The asymmetry in firms' mechanisms of cash holdings adjustments: evidence from the G-5 economies. Review of Quantitative Finance and Accounting, 53(2), 429-463.

17. Nguyen, H. A., \& Nguyen, T. H. (2020). The prediction of future operating cash flows using accrual-based and cashbased accounting information: Empirical evidence from Vietnam. Management Science Letters, 10(3), 683-694.

18. Srinivasan, S. (2020). Foreign competition and acquisitions. Journal of Corporate Finance, 60.

19. Sundaram, A. (2019). Trade liberalization and volatility: Evidence from Indian firms. Review of International Economics, 27(5), 1409-1426.

20. Yakymova, L., \& Kuz, V. (2019). The use of discriminant analysis in the assessment of municipal company's financial health. Economics and Sociology, 12(2), 64-78.

21. Zhang, M., He, X., Qin, F., Fu, W., \& He, Z. (2019). Service quality measurement for omni-channel retail: scale development and validation. Total Quality Management and Business Excellence, 30(sup1), S210-S226. 